\title{
MORAL COMPETENCY OF GRADE 8 AND 9 STUDENTS
}

\author{
Inese Augškalne \\ Riga Higher Institute of Religious Sciences, Latvia \\ Beatrise Garjāne \\ Riga Teacher Training and Education Management Academy, Latvia
}

\begin{abstract}
Sustainability of society demands diversified and balanced development of one's personality with morality-based quality of knowledge and skills. This can be achieved by respecting the mission of education, namely, to facilitate integrity of social and personal competencies. The goal of the study is to highlight the understanding of teachers and parents about ethical views and moral competency of the young people. The article reveals views of teenagers about values of people and life, about human beings and their obligations. The study combined the quantitative and qualitative research methods, and included content analysis of research documents, surveys and data of pedagogical observations. Moral opinions expressed by the students in the framework of the study reveal that their views on human beings, their obligations towards themselves and society are superficial and declarative. Knowledge about morality and values is notional; therefore, it does not act as motivation for civic action. Moral competency, which is based on relativism, is not complete.
\end{abstract} Keywords: human obligations, morality, moral competency, values.

\section{Introduction}

Due to increasing topicality of sustainable development, modern society pays greater attention to values such as moral competency and ethical beliefs of the young people. Global and national challenge in education is to ensure that reflection is based on experienced and internalised values, which make life meaningful and justify human activity (Freakley et al., 2008). Currently, regulations envisage that one of the tasks of primary education curricula is to develop a notion and understanding among students about moral and ethical values (Cabinet of Ministers Regulations No. 468, 2014). It can be assumed that great efforts are invested in defining the aims and content of value education because it is indicated as intertwining element in primary and general secondary education. Recommendations are made with regard to value education (Studente, 2014). However, it still seems that value education is not regarded as priority either in family or in school. Furthermore, in school value education is not equally present in all subject classes and class meetings, thus becoming sporadic, fragmented or even campaign-like. Value education in school should be as uniform system of upbringing which is developed and implemented by a 
team of teachers in collaboration with parents. Socialisation of a student (informal groups, mass media, social networks, etc.) has a diverse effect on values; however, the school, social interaction among students, as well as teachers and students, determine whether and to what extent the moral competency of the young people develops in the period of primary education, and to what extent it is present among last year students.

\section{Values as Core of Moral Competency in School}

Value is a conviction, mission or even philosophy (Gulla, 2010). Currently, the values are formed less on the grounds of parents' experience and rather on the grounds of students' own experience, or configurative value inheritance (Vērtībizglīitības perspektīvas Latvijas vispārējā izglītībā [Prospects for Value Education in General Education in Latvia] 2012). According to some authors, the significance of a phenomenon is attained by attributing value to it, and this action is intentional. However, this action is not intellectual because value is a result of experiencing the significance, namely, it is existentially emotional (Davis \& Steinbock, 2014). Awareness and understanding of values can be attained through reflection (through personal contemplation).Values can be viewed as expressions of moral obligation (Freakley, et al., 2008), or as experienced and individualised, namely, personally significant phenomena. In the first instance, they can be taught to a student: student will know (remember) them and will be able to name them. In the second instance, values are shaped through experience and emotions, through reflection on phenomena and events. Mainly those are mainly personally significant values which form the core of world view (Augškalne, 2012), justify and guide the quest for the meaning of life. Internalised values form human virtues - understanding of what is good, what action is considered good and responsible (Ryan, Bohlin, 1999). Concurrently, values are fundamental to competency, which is the strategic goal of education, and a competent individual, which is an ideal result of education (Tillla, 2015). Competency is a totality of knowledge, skills and attitudes that affect one's sense of responsibility, is reflected in one's actions, can be collated with set standards and developed (Lucia, Lepsinger, 1999: 3). Because of the integrative nature of competency, it is possible to analyse one particular aspect of competency, namely, moral competency (Sekerka, 2014; Podolsly, 2008.). Moral competency is formed by learning and reflection. Just as any other competency, formation of moral competency requires specific actions and moral development oriented process (Sekerka, 2016), which is manifested in knowledge and mainly ability of an individual - the student - to reflect upon their personal (instead of general or conventional) attitude towards issues that 
are significant to society or each individual and are highlighted in educational process.

\section{Methodology}

Phenomenology-driven study was conducted by gathering data with qualitative (written opinions, group and private discussions, pedagogical observations) and quantitative methods.

Content analysis of data was conducted with Weft QDA software. The software enables processing of texts in the Latvian language, to conduct qualitative analysis, as well as to highlight, encode and select specific parts of a text. The code word for this study was values; however, in order to identify the characteristics of internalised values, the personal pronoun $I /$ we was added to the code.

Contributors to the study were 30 students, who attend grades 8 and 9 in two private educational institutions in Riga and represent diverse cultures (for example, the Middle East or the South-East Asia), as well as think, speak and write in different languages (Latvian, Russian or English, which often are not even their native languages). These contributors were chosen to identify moral competence of students studying in multicultural environment.

\section{Moral Competency of Students Expressed through Value Reflection}

During the study, the research documents - written opinions of students, were obtained and analysed successively; pedagogical observations were made during the history class in grade 9 where the subject of holocaust was discussed (16 students present); and students were surveyed on the subject of moral values.

It is essential for a student to be aware of himself/herself as a part of nature and society, namely, a biological and social being; therefore, the study focused on nature and human life as values. During a social studies class, 30 students from grades 8 and 9 talked about natural resources, their limited availability and the need to preserve and restore the nature. At the end of discussion, students were given the following open-ended questions, which are topical from the perspective of UN Climate Conference held in Paris in 2015 and recent publications on website www.satori.lv:

1. Is the nature valuable per se, or is its value determined by us (people)?

2. How do you understand the phrase "valuable per se"?

3. Does the value of nature mean that we (people) have some obligations towards it? What kind of obligations? 
Proportional distribution of responses initially indicates that majority of students believe that value of nature is determined by people and that we talk about it only because it is significant (useful) to people (Table 1).

Table 1 Characterisation of Nature's Value

\begin{tabular}{|l|c|}
\hline \multicolumn{1}{|c|}{ Response } & Number of positive responses \\
\hline Nature is valuable per se & 8 \\
\hline Nature's value is determined by people & 19 \\
\hline Ambiguous response & 3 \\
\hline
\end{tabular}

As the questions were open-ended, the below-mentioned excerpts from responses reveal their views (the original way of expression and spelling is preserved; the authors have provided translation of replies given in Russian or English).

When explaining the inherent value of nature, students emphasise the general functions and aesthetics of nature (hereinafter quotations from essays are given in italics) - it purifies air, makes the life brighter... is the most beautiful thing in our lives; it provides elements for our existence, it produces substances just for us; it is the main resource for humanity, it is the foundation of all economies. However, more frequently we think about the beauty of nature, we draw inspiration and peace of mind from it. This is the dominant yet deinternalised opinion, because personal involvement is not revealed or maybe students believe that there is no need to reveal it in the study process. Only two students contemplated that nature means trees, rivers, rocks and many other things that are not actually created by a human being; it is not created for us alone, for our own use and with the aim to destroy other living beings, thus reminding about relations and interconnection between parts and the whole.

Internalisation, which is expressed by relating the issue to one's self and by the use of personal pronoun I (I think...; in my opinion ...; it seems to me), was observed only in four responses out of 30. Maybe it means that students do not relate themselves with the subject and do not see themselves as active and responsible part of society. That, on turn, raises concern about formation of moral competency, as well as the entire process of socialisation. But what concerns most, is the following reply: "unfortunately, we are not taught to preserve nature...", which, first of all, is not true because students are taught to preserve nature in natural and social science classes, as well as class meetings, and, secondly, it is an attempt to shift the responsibility away from one's self to those who do not teach.

Some students said that nature becomes valuable only because people determine its value on the grounds of extent to what it can be used. Students 
emphasise the diverse ways in which the nature can be used and on which the nature's value depend (we cut trees, use it as wood... we use land, trees, fruits, water for watering plants...).

Analysis of excerpts reveals that even if nature's inherent value was emphasised initially, the rest of the response focuses on reasons for its value to a human being. Many respondents (21 out of 30) perceive value from material perspective, namely, the things a human being extracts or gets from nature. Young people often confuse the material and moral meaning of value, thus giving grounds for concern about the understanding of values as one of the intended outcomes of educational process.

The second question regarding the meaning of phrase "valuable per se" was posed in order to determine the desire and ability to reflect upon general concepts (Table 2).

Table 2 Ability of Student to Reflect upon Concepts

\begin{tabular}{|l|c|}
\hline \multicolumn{1}{|c|}{ Response } & Number of responses \\
\hline Question is omitted & 11 \\
\hline $\begin{array}{l}\text { Attempt to shift from general to specific } \\
\text { concept }\end{array}$ & 5 \\
\hline Attempt to reflect upon general concept & 12 \\
\hline Negative response & 2 \\
\hline
\end{tabular}

Whenever the question was ignored (11 replies out of 30), students attempted to use daily experiences and general knowledge obtained in the educational process. This question seemed complicated because it is general and requires thinking and listening to one's self.

A part of respondents (5 out of 30) attempted to shift from the second general question to the first question about nature's value by once again referring to the ways in which nature can be used:

- Everyone sees the value per se when they come across places with nature in a bad state, dry land and no water.

- Value per se - no animal would survive without nature.

On few occasions ( 2 out of 30 ), the response was short and negative. It is impossible to comment these replies because they do not fit in the context.

- As far as I understand, the value does not exist per se.

- Value without value? Who needs it?

On several occasions (9 out of 30), the young people attempted to reflect upon general ideas; however, their thoughts and ways of expression are often unclear, sometimes controversial or declarative:

- It means that many things were not created with the aim to be valued. 
- I do not entirely understand what the value per se means because for me value is a concept used by people: something is valuable because it is rare, needed or beautiful.

- Value per se means that something is valuable but not needed; it merely exists without being used.

- I think that value per se is something that is not attached by us, the people, but exists on its own.

- Value per se characterises a thing or product which has many good characteristics, including being good for health.

- Value per se means that even if something means nothing to us, somebody else's life might depend on it.

- All things have inherent value; however, it is hard to identify and therefore we, the people, attach the value to these things.

- I understand it as something that existed before everything else, before a human being, yet still is essential.

These attempts to think suggest that a part of young people are willing to reflect upon general issues (Table 2), although it seems complicated and demands effort. Reflection upon issues of morality, in this case - upon values, is one of the characteristics of moral competency. It is possible that such general questions should be posed to students in all classes, in order to initiate (stimulate) independent analysis of problems discussed at school, to facilitate reflection and thus to form moral competency. Moral competency of students depends on their knowledge, their experience of personal values, and their ability to reflect upon personal attitude towards issues that are significant to the society or each individual and are highlighted in educational process.

Concurrently, the responses provided or avoided by students (Table 2) is a reminder and challenge for a teacher: How will a student form his/her moral competency without the sense and awareness of values? Opinions of students show insufficient individuation (induced self-education).

The third question regarding obligations of a human being towards nature from the students' perspective seemed to be the easiest one. All respondents named obligations which are determined by non-reflected conviction about nature as value: to take care of nature, not to pollute nature, to preserve flora, to treat nature with care, respect and love, to preserve and restore nature, not to disturb nature, not to kill animals for fur, to keep rivers clean, to save water. Only one response contained a superficial phrase that human beings have many obligations towards nature.

Internalisation expressed as relating obligations towards nature to one's self was evident in 12 replies saying that we take care of nature, it is our obligation to preserve nature, we take part in clean-up campaigns, and referring one's own 
personal action (Table 3). On 18 occasions, students did not relate these questions with themselves and talked about the others or the people. This separation or alienation of one's self from the essence of the question undoubtedly attests to formation of one's personality; however, it also shows the reluctance to be aware or assume responsibility in socially significant processes.

- Everyone talks about global warming; however, no one does anything.

- People must not do what shouldn't be done, for example, destroy trees.

- Human being is a selfish creature; and therefore, it often harms nature.

- $\quad$ People believe that nature has valuable materials which should be used to maximum by leaving only leftovers to nature itself.

Table 3 Internalisation of obligations of human being towards nature

\begin{tabular}{|c|c|}
\hline Level of internalisation & Number of replies \\
\hline Internalised & 12 \\
\hline Deinternalised & 18 \\
\hline
\end{tabular}

Furthermore, the content analysis reveals pedagogically grounded trend: positive responses emphasising the good we do for nature are internalised on nearly all occasions, while the negative are deinternalised, namely, detached from one's own actions.

Thus, deinternalised and instrumental perception of values dominate in the moral competency level among grade 8 and 9 students. The study let it be assumed that deinternalised views of students reveal their insufficiently critical assessment of reality and themselves, as well as still superficial moral competency which is merely on the level of general ideas about life. The attempts to reflect reveal insufficient individuation of personality, as well as insufficient readiness and lack of interest to devote greater attention to valuerelated issues.

The subjects of military-political nature touch upon value of human being as part of nature; therefore, this study contains pedagogical observation of ways the students assess historical events from perspective of morality, namely, discuss the holocaust during the history class in grade 9. After learning the facts and numbers that describe the mass killings of Jews during World War II and watching a documentary on the holocaust, students were urged to express their moral assessment of the holocaust. They were asked to give reasoned opinion and to think why it was possible to conduct this act of destruction of Jewish nation. 
All students regarded the holocaust as unjust, cruel and unjustified destruction of a nation, leading to death of the young and the old, children and women. Students indicated that Jewish nation did not threaten other nations or political powers. However, it was hard for students to say why the holocaust could be realised. Two students referred to the role of propaganda, one believed that other people simply were unaware of the events, while others objected to him saying that it is impossible, at least not for those living nearby, not to see the death camps.

Then students were asked to imagine that they have travelled in time and live during the period of holocaust; they were asked about their feelings and possible actions. All students in their individual responses indicated great fear. Three of the respondents said they cannot imagine being in such a situation (two of them come from the Middle East). Majority of students affirmed that they would be scared, and their families would isolate themselves and would be simply happy that the holocaust does not affect them. Only one student said that by all means he would be scared but still he would try to hide a persecuted person or help him/her get out of the country. Although students are aware that human life is a value, the readiness to act upon it was expressed only by this one respondent, while the rest of the class did not support this initiative. At the end of the class the teacher asked whether such an attitude of the majority could have been one of the reasons why the holocaust was realised. That brought silence to the class, and in the end a rhetoric comment was made by one of the students: "I never thought that in certain situations something might depend only on me."

This is just an insight into one of the classes focused on current and future life experience (life competency) of a student. But how many other classes with the same goal are there per week, for example? The opinions voiced by students highlight the impact of cultural background on the level of readiness and interest to talk about values, to discuss and understand the relation between values and personal characteristics, relation between values and one's goals in life, and to reflect upon the baseline and conditionality of values. However, another significant and broad subject for further studies is the competency of teachers to stand by students in their experience of values.

\section{Conclusions}

1. Moral competency of students is determined by knowledge of personal values, acquired by experiencing their meaning, and by ability to reflect upon personal attitude towards issues that are significant to society or each individual and are highlighted in educational process. 
2. Deinternalised and instrumental perception of values dominate in the moral competency level among grade 8 and 9 students; furthermore, the attempts to reflect reveal insufficient individuation of personality, as well as insufficient readiness and lack of interest to devote greater attention to value-related issues.

3. The competency of teachers to facilitate meaningful experience in educational process is still a significant and broad subject for further studies.

\section{References}

Augškalne, I. (2012). Profesionālo skolu audzēkņu pasaules uzskata izpēte. [Weltanshauung in vocational shool students] Promocijas darbs pedagoǵijas doktora zinātniskā grāda ieguvei. Jelgava, LLU (Ar rokraksta tiesībām)

Davis, Z., \& Steinbock, A., (2014). „Max Scheler”, The Stanford Encyclopedia of Philosophy Edward N. Zalta (ed.), Retrieved from: http://plato.stanford.edu/archives/sum 2014/entries/scheler/

Freakley, M., Burgh, G., \& MacSporran, L. T. (2008). Values Education in Schools. A resource book for student inquiry. Victoria: ACER Press

Gulla, A. (2010). Creating values in life: Personal, Moral, Spiritual, Family and Social Values. Indiana: Bloomington.

Lucia, A., \& Lepsinger, R. (1999). The Art and Science of Competency Models. San Francisko: Josey-Bass

Ministru kabineta noteikumi Nr. 468 [Cabinet of Ministers Regulations No. 468] (2014) Retrieved from: http://likumi.lv/doc.php?id=268342

Podolsky, O. Moral Competence of Contemporary Adolescents: Technology -based Ways of Measurement. Inaugural-Dissertation zurErlangung des Doktorgrades der Wirtschaftsund VerhaltenswissenschaftlichenFakultät der Albert-Ludwigs-Universität Freiburg im Breisgau. Retrieved from: https://www.freidok.uni-freiburg.de/dnb/download/4170

Ryan, K., \& Bohlin, K. (1999). Building Character in schools: Practical Ways to bring Moral Instruction to Life. San Francisko: Josey-Bass.

Sekerka, L. (2014). Ethics Training in Action: An Examination of Issues, Techniques and Development. Charlotte: Information Age Publishing

Sekerka, L. (2016). Ethics is a Daily Deal: Choosing to Build Moral strength as a Practice. Swiczerland: Springer International Publishing.

Studente, L. (2014). Veertībizglìtíba- kā to issteno skolās. [Value Education as it is Implemented in Schools] Retrieved from: http://www.lvportals.lv/visi/skaidrojumi/ 261732-vertibizglitiba-ka-to-isteno-skolas/

Tiḷ̦la, I. (2005). Sociokultūras mācīšanās organizācijas sistēma. Rīga: RaKa.

Vêretībizglìtības perspektî̀as Latvijas Vispārēja izglìtībā [Prospects for Value Education in General Education in Latvia] (2012) Retrieved from: http://visc.gov.lv/vispizglitiba/ saturs/dokumenti/2012/20120328_vertkonf_tezes.pdf

Weft QDA. Downloaded from: http://www.softpedia.com/get/Office-tools/Other-OfficeTools/Weft-QDA.shtml 